\title{
Analysis of roof greening technology impact on rain and meltwater retention
}

\author{
Elena Sysoeva ${ }^{1, *}$ and Margarita Gelmanova ${ }^{1}$ \\ ${ }^{1}$ Moscow State University of Civil Engineering (NRU MGSU), 29, Yaroslavskoye shosse, 129337, \\ Moscow, Russia
}

\begin{abstract}
Over the past 20 years, a large number of studies have been published on reducing storm runoff by various types of green roofs. This article analyzes the results of experimental studies presented in 39 publications on green roof runoff reduction in a climate similar to the climate of Russia: in Canada, the USA, Finland, Norway, France. An analytical review found that the ability of green roofs to retain rainfall varies from 20 to $99.5 \%$ depending on climatic conditions (duration and intensity of rains, duration of dry periods, solar radiation, temperature and humidity, wind conditions), the properties of green roof layers (moisture capacity of the substrate and a drainage layer, the substrate thickness), the type of vegetation, the geometry of a green roof (slope and orientation). Green roofs can be a useful tool for reducing urban storm water runoff. However, in order to ensure high efficiency, it is necessary to use green roof technology with other measures to reduce runoff.
\end{abstract}

\section{Introduction}

The process of urbanization leads to an increase in artificial impermeable surfaces in cities: roofs and roadways, thereby disrupting the natural hydrological cycle. There is an increase in rainwater and meltwater runoff intensity, a reduction of infiltration and evapotranspiration, the deterioration of wastewater quality due to increase in pollutants concentration $[1,2]$.

The building concentration and increase in load on engineering system lead to their wear and tear. Unsatisfactory technical condition of sewer systems in Russia, local damage of pipes of the rain sewer network and wells create problems in the operation of the rain sewer network and can lead to emergency situations: overflow of pipelines and wells and, as a result, flooding of roadways. Wear of sewer systems in most cities of Russia is extremely high, this is due to the discrepancy between the performance of the sewer systems, the vast majority of which were created at the end of the XX century, and the loads during intense rains (e.g., wear of sewer systems in Irkutsk - 48\% [3]; Kaliningrad-20-100\% [4]).

There is a problem of a sewer system congestion with storm water. It is necessary to carry out measures for effective management of rain and meltwater in areas with overloaded sewer systems. To solve this problem, in addition to the reorganization of worn-out engineering

\footnotetext{
*Corresponding author: SysoevaEV@mgsu.ru
} 
sewer systems, it is possible to use environmentally friendly energy-efficient, resourcesaving, biopositive building structures and technologies.

Arranging of green roofs can become the tool for managing storm water runoff in urban areas. Since roofs make up approximately $30-50 \%$ of urban impermeable surfaces, they contribute to a significant increase in runoff volume.

Transformation of conventional roofs into green roofs in Russia can lead to rainfall retention and runoff reduction in urbanized areas by maintaining rainfall in a green roof layers and delaying peak runoff during a rain, followed by evaporation of moisture from a green roof.

\section{Materials and methods}

The experience accumulated over the past 20 years shows the insufficiently deep study of the research topic among Russian researchers, in contrast to foreign ones. To date, around the world published more than 1000 works concerning green roofs (Web of Science).

In this paper, an analytical review of foreign articles with experimental studies on the rain and meltwater runoff from green roofs in the period 1975-2020 was performed (Web of Science) for countries with a climate similar to that of Russia: Canada, the USA, Finland, Norway, and France [5, 6]. Scientists from the selected countries published 374 articles, 39 of which provide the results of 32 experimental studies. Statistical data on foreign research are presented in figures 1 and 2.

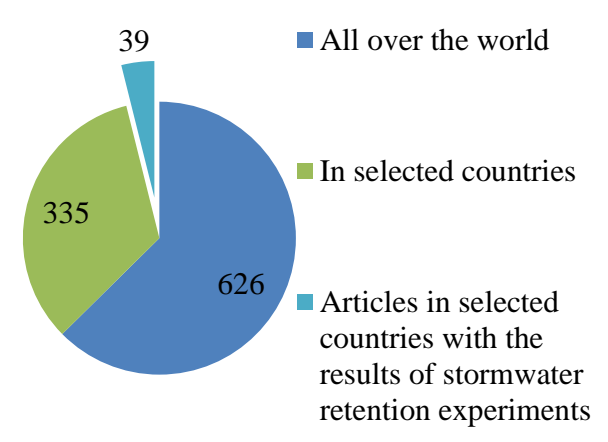

Fig. 1. Published scientific papers in WoS 19752020 on the topic of "green roofs".

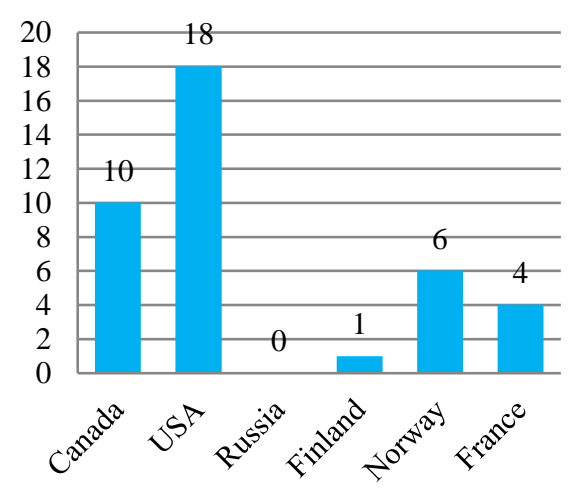

Fig. 2. Published scientific papers in WoS 1975-2020 in selected countries with the results of stormwater retention experiments.

Studies of stormwater retention on roofs with vegetation cover have received a lot of attention in recent years [7-20 et al.], but only a small part of them relate to long-term observations on large experimental areas.

Table 1 provides an overview of the results of laboratory and field experiments to determine the retention coefficient of rainwater and meltwater. Of the 32 experimental studies reviewed, 30 ones were conducted under real conditions, and 2 were made in the laboratory [21-22]. 
Table 1. Summary with some basic characteristics of reviewed publications on green roofs stormwater retention.

\begin{tabular}{|c|c|c|c|c|c|}
\hline Author. year & Study period & $\begin{array}{c}\text { Locatio } \\
\mathbf{n}\end{array}$ & $\begin{array}{c}\text { Substrate } \\
\text { thickness. } \\
\text { mm }\end{array}$ & $\begin{array}{c}\text { Roof } \\
\text { slope. \% }\end{array}$ & $\begin{array}{l}\text { Water } \\
\text { retentio } \\
\text { n. \% }\end{array}$ \\
\hline \multicolumn{6}{|c|}{ Finland } \\
\hline \multirow{2}{*}{$\begin{array}{l}\text { Krebs. G.. et } \\
\text { al.. } 2015\end{array}$} & $\begin{array}{l}7 / 08 / 2013- \\
20 / 10 / 2013 \\
\end{array}$ & \multirow{2}{*}{ Lahti } & \multirow{2}{*}{$\begin{array}{c}60-70 \\
+30-40\end{array}$} & \multirow{2}{*}{8} & 25 \\
\hline & $\begin{array}{c}9 / 05 / 2014-28 / 08 / \\
2014 \\
\end{array}$ & & & & 54 \\
\hline \multicolumn{6}{|c|}{ Norway } \\
\hline \multirow{6}{*}{$\begin{array}{c}\text { Johannessen. B.. et } \\
\text { al.. 2019. } 2018.2017 . \\
2016 \\
\text { Hamouz. V.. et al.. } \\
2018\end{array}$} & \multirow{4}{*}{$\begin{array}{l}1 / 05 / 2016-31 / 10 / 2016 \\
1 / 05 / 2017-31 / 10 / 2017\end{array}$} & Bergen & $\begin{array}{l}30 \\
80 \\
30\end{array}$ & 16 & $\begin{array}{l}22 \\
24 \\
21\end{array}$ \\
\hline & & Sanders & $\begin{array}{l}30 \\
80 \\
30\end{array}$ & 27 & $\begin{array}{l}33 \\
31 \\
27\end{array}$ \\
\hline & & \multirow{3}{*}{$\begin{array}{l}\text { Trondhei } \\
\mathrm{m}\end{array}$} & 30 & 16 & 52 \\
\hline & & & 80 & 16 & 46 \\
\hline & $\begin{array}{l}11 / 05 / 2017- \\
30 / 11 / 2017\end{array}$ & & $\begin{array}{c}200^{*} \\
30\end{array}$ & $\begin{array}{l}2 \\
2\end{array}$ & $\begin{array}{c}7 \\
27\end{array}$ \\
\hline & $\begin{array}{c}1 / 01 / 2010- \\
31 / 10 / 2010 \\
1 / 05 / 2012-31 / 10 / 2012\end{array}$ & Oslo & $\operatorname{Rr} * *$ & 5.5 & 7 \\
\hline $\begin{array}{l}\text { Scherer. L.A.. } \\
2018\end{array}$ & 2018 & lab & 50 & 2 & $16-71$ \\
\hline \multicolumn{6}{|c|}{ USA } \\
\hline $\begin{array}{c}\text { Abualfaraj. N.. et al. } \\
2018 \\
\text { Alvizuri.. J.. et al.. } \\
2017\end{array}$ & $06 / 2014-11 / 2017$ & $\begin{array}{l}\text { New } \\
\text { York }\end{array}$ & $\begin{array}{l}\text { XeroTerr } \\
\text { on textile } \\
\text { XF157 }\end{array}$ & $1-2$ & $75-79$ \\
\hline $\begin{array}{c}\text { Schultz. I.. et al.. } \\
2018\end{array}$ & $\begin{array}{l}1 / 02 / 2014- \\
31 / 01 / 2015\end{array}$ & Portland & $\begin{array}{c}75 \\
125\end{array}$ & 2 & $\begin{array}{l}23 \\
33\end{array}$ \\
\hline $\begin{array}{c}\text { Todorov. D.. } 2018 \\
\text { Carpenter. CMG. et } \\
\text { al.. } 2016\end{array}$ & $06 / 2010-11 / 2013$ & Syracuse & 95 & $1-15$ & $\begin{array}{l}95.9 \pm \\
3.6\end{array}$ \\
\hline $\begin{array}{c}\text { Hakimdavar. R.. et } \\
\text { al.. } 2014\end{array}$ & $\begin{array}{l}08 / 2011-01 / 2012 \\
08 / 2011-06 / 2012\end{array}$ & $\begin{array}{l}\text { New } \\
\text { York }\end{array}$ & $\begin{array}{c}32 \\
\text { Xero Flor } \\
\text { XF301 + } \\
\text { 2FL } \\
\end{array}$ & 2 & $25-89$ \\
\hline $\begin{array}{c}\text { Carson. T.B.. et al. . } \\
2013\end{array}$ & $\begin{array}{l}06 / 2011-06 / 2012 \\
06 / 2011-06 / 2013 \\
06 / 2011-04 / 2014\end{array}$ & $\begin{array}{l}\text { New } \\
\text { York }\end{array}$ & $\begin{array}{c}32 \\
100-200 \\
100\end{array}$ & 2 & $\begin{array}{l}36 \\
47 \\
61 \\
\end{array}$ \\
\hline $\begin{array}{c}\text { Gregoire. B.G.. et al.. } \\
2011\end{array}$ & $\begin{array}{c}25 / 02 / 2009- \\
1 / 02 / 2010\end{array}$ & Storrs & 102 & 2 & 51.4 \\
\hline $\begin{array}{l}\text { Spolek. G.. et al.. } \\
2008\end{array}$ & 10/2004-04/2007 & Portland & $\begin{array}{c}100-150 \\
100-150 \\
150 \\
\end{array}$ & 2 & $\begin{array}{l}12 \\
17 \\
25 \\
\end{array}$ \\
\hline Kurtz. T.. et al.. 2008 & $\begin{array}{c}05 / 2002-06 / 2008 \\
03 / 2007-06 / 2008 \\
03 / 2007-06 / 2008\end{array}$ & Portland & $\begin{array}{c}125 \\
150 \\
75\end{array}$ & 2 & $\begin{array}{l}56 \\
74 \\
64\end{array}$ \\
\hline $\begin{array}{l}\text { Berkompas. B.. et al.. } \\
2008\end{array}$ & $\begin{array}{l}02 / 2007-12 / 2007 \\
04 / 2007-06 / 2007 \\
10 / 2007-12 / 2007\end{array}$ & Seattle & $\begin{array}{c}150 \\
100-125 \\
150\end{array}$ & $\begin{array}{c}4-21 ; 4-8 \\
0-25 \\
6\end{array}$ & $\begin{array}{c}30.5 \\
33 \\
17.1 \\
\end{array}$ \\
\hline
\end{tabular}




\begin{tabular}{|c|c|c|c|c|c|}
\hline $\begin{array}{c}\text { Moran. A.C.. et al.. } \\
2005\end{array}$ & $\begin{array}{c}04 / 2003-09 / 2004 \\
07 / 2004-09 / 2004 \\
\end{array}$ & $\begin{array}{l}\text { Goldsbo } \\
\text { ro }\end{array}$ & $\begin{array}{c}75 \\
100 \\
\end{array}$ & 7 & $\begin{array}{l}63 \\
55 \\
\end{array}$ \\
\hline $\begin{array}{l}\text { Hutchinson. D.. et al.. } \\
2003\end{array}$ & $01 / 2002-04 / 2003$ & Portland & $100-125$ & 2 & 69 \\
\hline $\begin{array}{c}\text { Berghage R. et al.. } \\
2010\end{array}$ & 08/2007-07/2009 & Chicago & 76 & 2 & 74 \\
\hline $\begin{array}{l}\text { Bliss. D. J.. et al.. } \\
2009\end{array}$ & 08/2006-01/2007 & $\begin{array}{c}\text { Pittsburg } \\
\text { h }\end{array}$ & 140 & 2 & 22 \\
\hline $\begin{array}{l}\text { Hathaway. A. M.. et } \\
\text { al.. } 2008\end{array}$ & 04/2003-06/2004 & $\begin{array}{l}\text { Goldsbo } \\
\text { ro }\end{array}$ & 75 & no data & 74 \\
\hline $\begin{array}{c}\text { Carter. T. L..\& } \\
\text { Rasmussen. T. C.. } \\
2007\end{array}$ & $11 / 2003-11 / 2004$ & Athens & no data & 2 & 78 \\
\hline \multicolumn{6}{|c|}{ Canada } \\
\hline $\begin{array}{l}\text { Connelly. M.. et al.. } \\
2005\end{array}$ & $01 / 2005-12 / 2005$ & $\begin{array}{c}\text { Vancouv } \\
\text { er }\end{array}$ & $\begin{array}{c}75 \\
150 \\
\end{array}$ & 2 & $\begin{array}{l}29 \\
26 \\
\end{array}$ \\
\hline Liu. K.Y.. et al.. 2005 & $\begin{array}{l}03 / 2003-11 / 2004 \\
04 / 2003-11 / 2004 \\
\end{array}$ & Toronto & $\begin{array}{c}75 \\
100 \\
\end{array}$ & no data & 57 \\
\hline Hill. J.. et al.. 2017 & $\begin{array}{l}05 / 2013-10 / 2013 ; \\
05 / 2014-10 / 2014\end{array}$ & Toronto & 100. 150 & 2 & $\begin{array}{c}\text { with } \\
\text { watering } \\
-70 ; \\
\text { without } \\
-50 \\
\end{array}$ \\
\hline $\begin{array}{c}\text { Sims. A. W.. et al.. } \\
2019\end{array}$ & $\begin{array}{c}\text { 28/07/2013- } \\
11 / 11 / 2013 ; 11 / 04 / \\
2014-21 / 10 / 2014\end{array}$ & London & 100 & no data & no data \\
\hline $\begin{array}{c}\text { Akther. M.. et al.. } \\
2018\end{array}$ & 2018 & lab & $\begin{array}{c}100.150 . \\
200\end{array}$ & 1 & no data \\
\hline $\begin{array}{c}\text { MacIvor. J. S.. et al.. } \\
2011\end{array}$ & $\begin{array}{l}05 / 2007-10 / 2007 ; \\
05 / 2008-10 / 2008\end{array}$ & Halifax & 60 & no data & $49-73$ \\
\hline $\begin{array}{c}\text { Vander Linden. K.. \& } \\
\text { Stone. M.. } 2009\end{array}$ & $\begin{array}{l}2 / 06 / 2006- \\
22 / 10 / 2006\end{array}$ & $\begin{array}{c}\text { Waterlo } \\
\text { o }\end{array}$ & 35 & no data & 31.5 \\
\hline $\begin{array}{l}\text { Van Seters. T.. et al.. } \\
2009 \\
\text { MacMillan. G.. } 2004\end{array}$ & $\begin{array}{l}\text { 05/2003-11/2003; } \\
\text { 06/2004-11/2004; } \\
04 / 2005-08 / 2005\end{array}$ & Toronto & 140 & 10 & 63 \\
\hline $\begin{array}{c}\text { Berghage. R.D.. et } \\
\text { al.. } 2009 \\
\end{array}$ & $01 / 2005-11 / 2005$ & $\begin{array}{l}\text { Universi } \\
\text { ty Park }\end{array}$ & $80-100$ & 8 & 52.6 \\
\hline \multicolumn{6}{|c|}{ France } \\
\hline $\begin{array}{c}\text { Versini. P.-a.. et al.. } \\
2015 \\
\text { Gromaire. M. C.. et } \\
\text { al.. } 2013 \\
\text { Ramier. D.. et al.. } \\
2013 \\
\end{array}$ & 06/2011-08/2012 & Trappes & $\begin{array}{c}30 \\
30 \\
30 \\
150 \\
150 \\
150\end{array}$ & $1-2$ & $\begin{array}{l}51 \\
63 \\
69 \\
64 \\
71 \\
74 \\
\end{array}$ \\
\hline $\begin{array}{c}\text { Yilmaz. D.. et al.. } \\
2016\end{array}$ & 06/2011-03/2013 & Nantes & $\begin{array}{c}80 \\
120\end{array}$ & 3 & $\begin{array}{l}28 \\
80\end{array}$ \\
\hline
\end{tabular}

* non-vegetated roof

** reference roof

There are many studies that prove the influence of rain characteristics (duration and intensity), duration of the dry periods and climate (solar radiation, temperature and humidity, wind conditions) on the precipitation retention by a green roof. Precipitation retention is inversely proportional to the amount of precipitation [23], and decreases with increasing precipitation intensity [24]. In the article [25] it is reported that the extensive green roof in Toronto during the wet period retained $42 \%$ of precipitation, and during the dry period much more $(70-93 \%)$. 
In the experimental studies presented in the table, green roofs with a substrate thickness of 30mm (extensive type of green roof) and $150 \mathrm{~mm}$ (semi-intensive / intensive type of green roof) were most often considered. Moreover, the greater thickness of the substrate led to an increase in the retention rate, which is due to the greater moisture capacity. The composition of the substrate and its moisture capacity will also increase this indicator.

In addition to the geometric and physical properties of the roof substrate, precipitation retention is influenced by the roof geometry: its slope and orientation to the cardinal directions. However, foreign studies do not consider the combined influence of slope and orientation. The influence of these factors on the green roof runoff coefficient remains poorly understood. In a small experiment of American scientists [26], there were no differences in the average precipitation retention by the modular green roof system $(n=42.1 \%)$, located with a South orientation, with slope angles of 1, 20 and 40. According to the authors, such contradictory results may be due to a short study period ( 9 months), a small area of vegetation and South orientation. A number of studies by other scientists show that the retention of stormwater runoff from green roofs decreases with increasing tilt angle [27].

It is important to study the performance of green roofs in winter conditions, which is especially relevant for the Northern countries, including the Northern parts of Russia. 16 studies [28-38 et al.] out of 32 presented in the table were conducted for winter conditions, but they mainly took into account liquid precipitation. In the study [39], scientists divided rain events into 4 categories based on the amount of precipitation $(0-10 \mathrm{~mm} ; 10-20 \mathrm{~mm}$; 20$40 \mathrm{~mm} ; 40 \mathrm{~mm}$ and more). for each of the selected categories, precipitation retention was recorded in all seasons. For events with rainfall of 10-20 mm and 20-40 precipitation retention was greatest in summer and least in winter (e.g., for a sample green roof W118 precipitation retention in the summer $70 \%$ and $28 \%$ in winter), for fall and spring this value was between summer and winter. While for categories $0-10 \mathrm{~mm}$ and $40 \mathrm{~mm}$ and more, contrary to expectations, precipitation retention in all 4 seasons was the same $(0-10 \mathrm{~mm}$ $100 \%$; $40 \mathrm{~mm}$ and more $-20 \%$ on average). Other researchers, having divided rain events by their size into 3 categories $(0-20 \mathrm{~mm} ; 20-40 \mathrm{~mm} ; 40 \mathrm{~mm}$ or more), came to similar conclusions [40]. In articles [41-43], scientists also divided rain events by their size into 3 categories $(0-5 \mathrm{~mm} ; 5-19 \mathrm{~mm} ; 19 \mathrm{~mm}$ and more), but the retention rate in these categories did not change significantly by season.

In most studies, the maximum precipitation retention on a green roof occurred in summer, and the minimum in winter. So, in the study [44], the average retention in summer was $92 \%$ and $66 \%$ in winter. In [45], this indicator was equal to $42 \%$ in summer and $12 \%$ in winter. A similar pattern in seasonal results was demonstrated by a number of other researchers [4647].

The complexity of describing and predicting the hydrological behavior of water in green roofs lies in various criteria for evaluating precipitation retention (differences in study periods, differences in the allocation of rain event size categories, variable accounting for solid precipitation, etc.). to predict the hydrology of green roofs, several attempts have been made to model the retention capacity of green roofs using the SWMM stormwater management model [48]. However, the resulting models will only be suitable for describing specific types of "green" roofs under certain climatic conditions.

Thus, there is still a lack of knowledge regarding the simulation of precipitation retention by green roofs, since all indicators in the model reflect a certain type of green roof and its location, experimental research is needed to build new models.

\section{Results}

It was found that the green roofs stormwater retention rate varies from 20 to $99.5 \%$ for the selected countries (figure 3 ). 


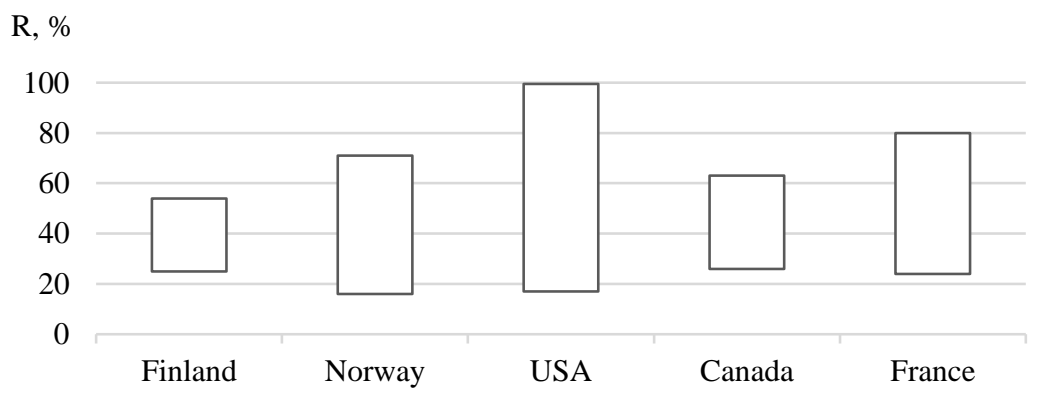

Fig. 3. Range of green roof rainfall retention rates in selected countries.

A number of significant factors that affect the coefficient of green roof stormwater retention have been identified. Green roof precipitation retention depends on the climatic characteristics of the territory (duration and intensity of rainfall, length of dry season, solar radiation, temperature and humidity, wind conditions), the properties of green roof layer (the moisture capacity of the substrate, drainage layer, type of drainage layer, thickness of substrate), type of vegetation, the geometry of a green roof (slope and orientation), as well as the age of the roof (virtually unexplored).

According to the results of the analytical review, the geometric and physical properties of the roof substrate (its moisture capacity, thickness and composition) have the greatest impact on the rain and meltwater retention of green roofs. The thickness of the substrate is a key factor that should be taken into account when design green roofs.

\section{Discussion}

Such a wide range of results on the ability of a green roof to retain precipitation, as describe in this work, is demonstrated by other review articles of this kind. For example, in the article [49], German scientists Mentens et al. in 2006 summarized data on experimental studies on reducing runoff from green roofs in Germany for the period 1987-2003. The annual decrease in runoff from extensive green roofs was $27-81 \%$, from intensive $-65-85 \%$.

A similar range was found in a review article by American scientists [50], where data were collected for the period 2004-2013. The retention of stormwater runoff by a green roof was in the range of 30 to $86 \%$.

\section{Conclusions}

Thanks to the ability to retain precipitation in the substrate and evapotranspiration processes, green roofs can reduce the volume and intensity of runoff in densely built-up urban areas from 20 to $99.5 \%$.

Over the past twenty years, significant research efforts have been made to better understand the effectiveness of green roofs in addressing the issue of regulating the volume of rainwater and meltwater. But it is still not known how the slope of a green roof and its orientation will affect the retention rate. Also, of interest for further work is the study of the ability of green roofs to retain water in winter conditions.

In Russia, buildings with green roofs have started to appear relatively recently, in cities such as Moscow, St. Petersburg, Yekaterinburg, Kaliningrad, Tver, Voronezh, and some others. In Russia, such specialists as V. I. Telichenko, M. Y. Slesarev, A. A. Benuzh, E. A. Korol and N. S. Shushunova were engaged in green roofs. However, the arrangement of green roofs cannot become widespread in the country without theoretical and experimental 
confirmation of the effectiveness and safety of the technology. There is a need for practical testing and numerical assessment of the impact of green roofs on the environmental safety of urbanized territories, taking into account Russian climatic factors and regulatory and technical requirements for buildings.

\section{References}

1. G. Krebs, K. Kuoppamäki, T. Kokkonen, H. Koivusalo, Hydrological Processes 30(2), 250-262 (2015) DOI:10.1002/hyp.10605

2. B. Gisvold Johannessen, V. Hamouz, A. Seifu Gragne, T. Merete Muthanna, Journal of Hydrology 569, 816-828 (2019) DOI: 10.1016/j.jhydrol.2019.01.004.

3. L.V. Makotrina, News Proceedings of Universities. Investments. Constructions. Real estate 7(1), 69-76 (2017)

4. N.L Velikanov, V.A. Naumov, S.I. Koryagin, A.V. Moysa, Technical and technological problems of service 2(40), 14-20 (2017)

5. M.J. Kottek, C. Grieser, B.B. Rudolf, F. Rubel, Meteorol. Z. 15, 259-263 (2006) DOI: 10.1127/0941-2948/2006/0130

6. F. Rubel, M. Kottek, Meteorol. Z. 19, 135-141 (2010) DOI: 10.1127/09412948/2010/0430

7. B. Johannessen, T. Muthanna, B. Braskerud, Water 10(6), 671 (2918) DOI:10.3390/w10060671

8. B. Johannessen, T. Muthanna, Hydraulic perfomance of extensive green roofs in coldclimate (NOVATECH, 2016)

9. V. Hamouz., J. Lohne, J. Wood, T. Muthanna, Water 10(3), 263 (2018) DOI: org/10.3390/ w10030263.

10. B.G. Johannessen, H.M. Hanslin, T.M. Muthanna, Ecological Engineering 106, 436447 (2017) DOI: 10.1016/j.ecoleng.2017.06.011

11. N. Abualfaraj, J. Cataldo, Y. Elborolosy, D. Fagan, S. Woerdeman, T. Carson, F.A. Montalto, Water 10(11), 1494 (2018) DOI:10.3390/w10111494

12. J. Alvizuri, J. Cataldo, L.A. Smalls-Mantey, F.A. Montalto, Energy and Buildings 151, 455-468 (2017) DOI: 10.1016/j.enbuild.2017.06.020

13. B. Berkompas, K.W. Marx, H.M. Wachter, D. Beyerlein, B. Spencer, Low Impact Development for Urban Ecosystem and Habitat Protection, 1-10 (2008) DOI:10.1061/41009(333)8

14. A.C. Moran, W. Hunt, J. Smith, Manage. Watersheds Hum.Nat. Impacts 1-12 (2005) http://dx.doi.org/10.1061/40763(178)99

15. K.Yu. Liu, J. Minor, Conference Awards \& Trade Show Washington DC, 1-11 (2005)

16. J. Hill, J. Drake, B. Sleep, L. Margolis, Journal of Hydrologic Engineering 22(8), 04017019 (2017) DOI:10.1061/(asce)he.1943-5584.0001534

17. A.W. Sims, C.E. Robinson, C.C. Smart, D.M. O'Carroll, Journal of Hydrology 577, 123972 (2019) DOI: 10.1016/j.jhydrol.2019.123972

18. J.S. MacIvor, M.A. Ranalli, J.T. Lundholm, Annals of Botany 107(4), 671-679 (2011) doi:10.1093/aob/mcr007

19. K. Vander Linden, M. Stone, Water Quality Research Journal 44(1), 26-32 (2009) DOI:10.2166/wqrj.2009.004 
20. G. MacMillan, Proc. of the Second North American Green Roof Conference: Greening Rooftops for Sustainable Communities (Portland, 2004)

21. L.A. Scherer, Comparing experimentally measured runoff coefficients with field observations for detention-based roofs: master's thesis (Trondheim, Norway, 2018)

22. M. Akther, J. He, A. Chu, C. Valeo, C. Khan, B. van Duin, Water Science and Technology wst2018275 (2018) DOI: 10.2166/wst.2018.275

23. T.L. Carter, T.C. Rasmussen, Journal of the American Water Resources Association 42(5), 1261-1274 (2007) DOI:10.1111/j.1752-1688.2006.tb05299.x

24. N. Van Woert, D.B. Rowe, J.A. Andresen, C.L. Rugh, L. Xian, HortScience 40, 659664 (2005)

25. T. Van Seters, L. Rocha, D. Smith, G. MacMillan, Water Quality Research Journal 44(1), 33-47 (2009) doi:10.2166/wqrj.2009.005

26. D. Murphy, S. Morgan, S. Celik, B. Retzlaff, Journal of living architecture 5(1), 16-30 (2018)

27. K.L. Getter. D.B. Rowe, J.A. Andresen, Ecological Engineering 31, 225-231 (2007)

28. B.G. Gregoire, J.C. Clausen, Ecol. Eng. 37, 963-969 (2011) http://dx.doi.org/10.1016/j.ecoleng.2011.02.004

29. T. Kurtz, Low Impact Dev. Urban Ecosyst. Habitat Prot. 11, 1-10 (2008) http://dx.doi.org/10.1061/41009(333)10z

30. D. Hutchinson, P. Abrams, R. Retzlaff, T. Liptan, Green. Rooftops Sustain. Commun. (2003) www.greenroofs.ca

31. R. Berghage, C. Miller, B. Bass, D. Moseley, K. Weeks, Eighth Annual Green Roof and Wall Conf., 1-13 (2010)

32. D.J. Bliss, R.D. Neufeld, R.J. Ries, Environ. Eng. Sci. 26, $407-417$ (2009) DOI:10.1089/ees.2007.0186

33. M. Connelly, K. Liu, National Research Council of Canada (2005)

34. R.D. Berghage, D. Beattie, A.R. Jarrett, C. Thuring, F. Razaei, T.P. O'Conner, EPA 600-R-09-026 (National Risk Management Research Laboratory Office of Research and Development U.S. Environmental Protection Agency, Cincinnati, 2009)

35. P. Versini, D. Ramier, E. Berthier, B. de Gouvello, J. Hydrol 524, 562-575 (2015) http://dx.doi.org/10.1016/j.jhydrol.2015.03.020

36. M.C. Gromaire, D. Ramier, M. Seidl, E. Berthier, M. Saad, B. de Gouvello, Incidence of extensive green roof structures on the quantity and the quality of runoff waters - first results from an experimental test bench in Paris area (NOVATECH, 2013)

37. D. Ramier, E. Berthier, D. Gallis, A. Dussuchale, P. Pinta, P.A. Versini, B. De Gouvello, What Innovations for Sustainable Management Of Rainwater In Urban Areas (Nantes, France, 2013)

38. D. Yilmaz, M. Sabre, L. Lassabatère, M. Dal, F. Rodriguez, European Journal of Environmental and Civil Engineering 20(3), 344-362 (2016) DOI: 10.1080/19648189.2015.1036128

39. T.B. Carson, D.E. Marasco, P.J. Culligan, W.R. McGillis, Environ. Res. Lett. 8, 1-13 (2013) http://dx.doi.org/10.1088/1748-9326/8/2/024036

40. R. Hakimdavar, P.J. Culligan, M. Finazzi, S. Barontini, R. Ranzi, Ecol. Eng. 73, 494508 (2014) http://dx.doi.org/10.1016/j.ecoleng.2014.09.080

41. D. Todorov, C.T. Driscoll, S. Todorova, Hydrological Processes 32(16), 2471-2482 (2018) doi:10.1002/hyp.13175 
42. C.M.G. Carpenter, D. Todorov, C.T. Driscoll, M. Montesdeoca, Environmental Pollution 218, 664-672 (2016) DOI: 10.1016 / j.envpol.2016.07.056

43. D. Todorov, C.T. Driscoll, S. Todorova, M. Montesdeoca, Science of The Total Environment 625, 928-939 (2018) DOI: 10.1016/j.scitotenv.2017.12.085

44. E. Fassman-Beck, E. Voyde, R. Simcock, Y.S. Hong, Journal of Hydrology 490, 11-20 (2013)

45. G. Spolek, Urban Ecosyst 11, 349-359 (2008) http://dx.doi.org/10.1007/s11252-0080061-z

46. I. Schultz, D.J. Sailor, O. Starry, Journal of Hydrology: Regional Studies 18, 110-118 (2018) DOI: 10.1016 / j.ejrh.2018.06.008

47. A.M. Hathaway, W.F. Hunt, G.D. Jennings, Trans ASABE 51, $37-44$ (2008) DOI: $10.13031 / 2013.24225$

48. B.G. Johannessen, V. Hamouz, A.S. Gragne, T.M. Muthanna, Journal of Hydrology 569, 816-828 (2019)

49. J. Mentens, D. Raes, M. Hermy, Landscape and Urban Planning 77, 217-226 (2006)

50. Y. Li, J. Babcock, W. Roger, A Journal of the International Association on Water Pollution Research 69, 727-738 (2014) 